\title{
The Development of Cacao Oil Industry Chain Value Model to Increase Sustainable Additional Value
}

\author{
Sudirman Zaid ${ }^{1)}$, Dedy Takdir Syaefuddin ${ }^{2)}$, Halim $^{2)}$ \\ 1. Management Studies Program, Faculty of Economics and Business, Halu Oleo University Faculty of \\ Economics and Business Building, Kampus Bumi Tridharma Universitas Halu Oleo \\ 2. Management Studies Program, Faculty of Economics and Business Halu Oleo University
}

\begin{abstract}
This research aims to develop the cocoa oil industry value chain model in the cocoa commodity node of North Kolaka Regency of Southeast Sulawesi Province in order to increase the added value of the business sustainably. This research was conducted at 4 (four) districts in the cocoa commodity node in North Kolaka Regency, i.e.; Pakue subdistrict, Pakue Tengah subdistrict, Pakue Utara subdistrict, and Batu Putih subdistrict, where in each of the districts assigned a sample of 25 respondents using purposive sampling technique, therefore the total respondents were 100 respondents. The analysis used is Activity Based Costing $(A B C)$ and Focus Group Discussion (FGD) and Hayami method. The results showed that the development model of cocoa oil industry value chain produced is projected to; (1) increase the selling price of products, (2) lower the purchase price of the main raw materials (dried cocoa beans), (3) reduce the costs of other inputs contribution, (4) increasing the value of output, (5) increasing the value-added products, (6) increase profits, (7) increase profit margins, and (8) reduces the margin portion of remuneration for labor factors of production.
\end{abstract}

Keywords: Model Development, Value Chain, Value Added, Activity Based Costing, Hayami method.

\section{Background}

\section{Introduction}

Cocoa oil industry development in the region leading commodity knot in Southeast Sulawesi cocoa done in order to increase the added value of commodities as well as to prevent the cocoa farmers from selling their cocoa production in the form of logs. However, it is yet to achieve optimal results. It can be seen from the level of competitiveness of the cocoa oil industry in Southeast Sulawesi which is still at moderate levels (Zaid, 2016). The results of a preliminary survey showed that the main cause is the increased production volumes tend to be less due to higher operating cost from the raw materials gain cost, the cost of production, and marketing costs. In addition, the decreased volume of cocoa oil production in Southeast Sulawesi is also caused by lower selling prices. The low price of the product is due to the low market access that result in low demand. Demand for production only leads to collecting traders which impedes to the wider market access because business communities seem to be carried away by the rhythm of the collecting traders who eventually become the determinant of the selling price. Referring to these conditions, it is then very necessary to build strategic procedure to reduce costs, increase production volume and selling prices, and add value. The Strategic procedure in this paper is to develop the models of cocoa oil industry value chain in order to reduce costs, increase production volume and selling prices as well as expand market access in order to increase the added value in a sustainable manner.

\section{Research purposes}

This research aims to develop cocoa oil industry value chain model to increase cocoa oil industrial added value in a sustainable manner. The purpose of this study can be described as follows:

a. Constructing the initial models of cocoa oil industry value chain.

b. Performing analysis of Activity Based Costing (ABC) to the initial model of cocoa oil industry value chain in order to select and analyze which value chain activities that can provide added value.

c. Constructing development models of cocoa oil industry value chain.

d. Calculating the amount of projected value added of cocoa oil industry which can be obtained from the development model of cocoa oil industry value chain by using Hayami method.

\section{Research Methods}

Research sites

This study will be conducted in the Southeast Sulawesi's leading commodity node of cocoa, Agropolitan Lembah Laniva, North Kolaka. The Agropolitan Area Lanipa Valley is located in 4 (four) subdistricts, namely; (1) District Pakue, District Pakue Tengah, District Pakue North, and District of Batu Putih. 


\section{Population and Sample}

The population in this study is the whole business community of cocoa oil processing industry in the Agropolitan Lembah Lanipa region, North Kolaka, Southeast Sulawesi province, which includes four (4) subdistricts, , namely; (1) District Pakue, District Pakue Tengah, District Pakue North, and District of Batu Putih Based on the characteristics of the population, then subsequently determined by purposive sampling as many as 25 respondents in each district, therefore, the total respondents in this study were 100 respondents.

\section{Analysis Technique}

Analysis techniques used in this study conducted by two (2) phases;

a. The first stage; developing models cocoa oil industry value chain. Analysis were performed by: (1) conducting Participatory Appraisal of all value chain activities i.e. the activity of the raw materials, production, marketing and service in order to establish the initial format of the value chain by reference to Porter Value Chain Model. (2) FGD by involving all related parties such as; core and support businesses community, institutions, government, and consumers in order to obtain the problems and solutions for the value chain activities which would then be used in forming the value chain development model using activity-based costing (ABC).

b. After the model of the development of the value chain is formed, then continued with HAYAMI method which is used to calculate the amount of the projected increase in the added value of business acquired from value chain development model that has been constructed. If the added value gained from the value chain development model is greater than the previous value chain model, then the development model is ready to be applied.

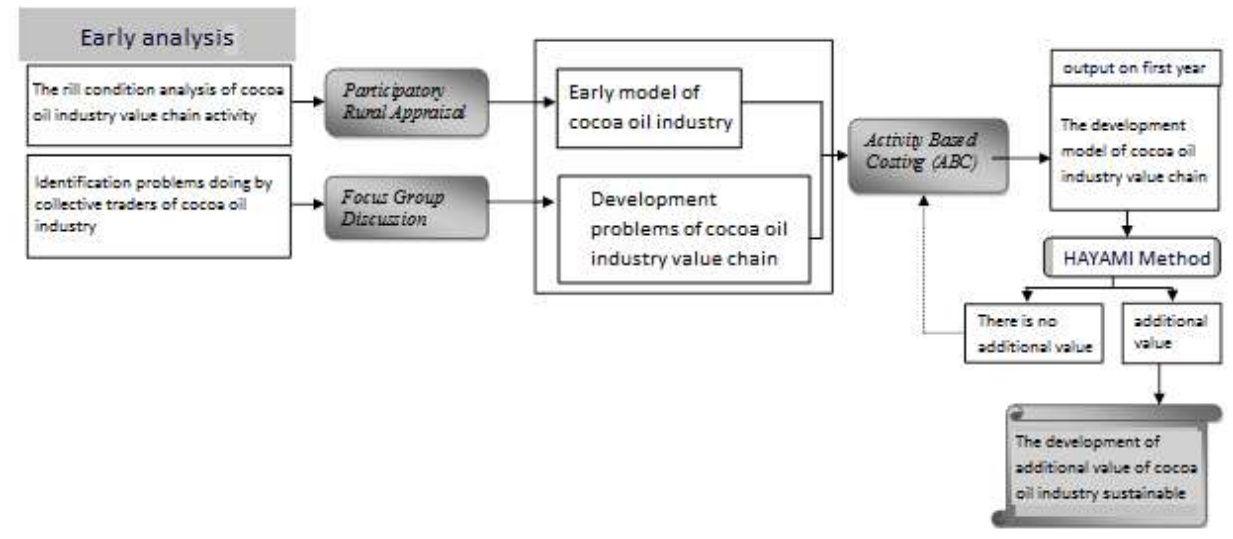

Figure 1 Research Analysis Framework

\section{Result And Discussion}

Research development of Cocoa Oil Industry Value Chain Model to Increase Sustainable Additional value that focuses on developing models of cocoa oil industry value chain in order to reduce cost and increase the additional value of business continuously.

\section{Initial Model of Cocoa Industry Value Chain}

The first stage of this research is to arrange an initial model of the cocoa oil industry value chain that is appropriate with the real conditions and characteristics that occurred in the current research location. Preparation of this initial model is applied participatory appraisal technique by doing comprehensive understanding related to the value chain characteristic of cocoa oil industry in research object. The value chain model used as a reference in this study is Porter Value Chain Model, which is a value chain model that uses 5 (five) main activities namely; (1) inbound logistics; (2) outbound logistics; (3) production; (4) marketing; And (5) service. In this research, the value chain model that will be built on 3 (three) value chain activities, namely; (1) raw material chain; (2) the production chain; and (3) the marketing chain. This is done with the consideration that outbound logistics and service have not been fully applied in the cocoa oil industry in the research location.

\section{Initial Model of Industrial Raw Chain of Cocoa Industry}

The initial model of the raw material chain is a model in which raw material supply flows are obtained for cocoa oil industry production activities. Generally, the initial model of the cocoa oil industry raw materials chain at the research site can be seen in Figure 2. 


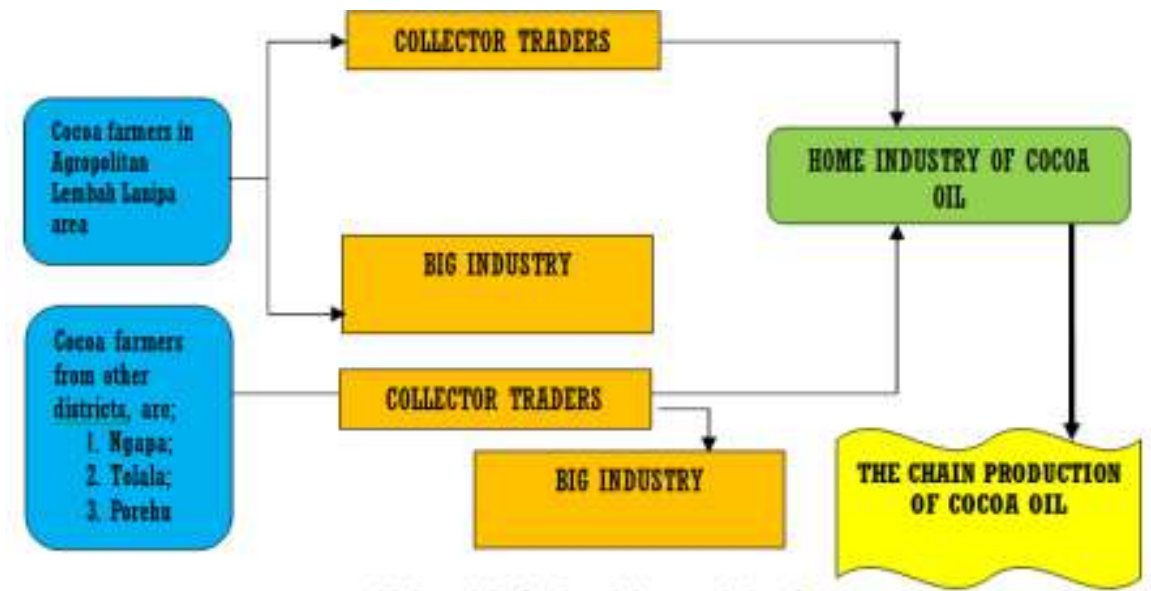

Figure 2. Initial Model of Industrial Raw Chain of Cocoa Industry

Based on Figure 2, it can be seen that the raw material chain model for the cocoa oil industry on research location generally comes from 2 (two) sources, namely;

1) Collector Traders in Agropolitan Lembah Lanipa Area.

If the supply of raw materials is directly from cocoa farmers in the Agropolitan Lembah Lanipa area is considered insufficient for the production process, then another alternative of supplier of cocoa oil industry is from collecting traders located in the Agropolitan Lembah Lanipa area. However, the supply of raw materials from this source is quite expensive, reaching of Rp.20.000, - per kilogram. This is due to the determination of the margins set by the collecting traders.

2) Collector Traders from other Sub-districts.

The next alternative place for raw materials for the cocoa oil industry is the collecting traders located in other sub-districts outside the Agropolitan Lembah Lanipa area. If the supply of raw materials from the two previously described sources is insufficient for production activities, then the cocoa oil industry operators will purchase raw materials from collecting traders located in other sub-districts. The amount of supply of raw materials from this source is also very limited. This is because most of the cocoa products in these areas are sold directly to large companies located in South Sulawesi such as; Luwu Timur Regency, Luwu Regency, and Palopo City. The purchase price of raw materials from this source is relatively the same as the collecting traders from Agropolitan Lembah Lanipa area which reaches Rp. 20,000 , - per kilogram. This is because the location is quite far, which makes cocoa industry business community spend spend transport costs of Rp. 200,000, - / 500 pounds.

\section{Initial Model of Cocoa Oil Industry Production Chain}

The initial model of the cocoa oil industry production chain is a model in which the process and production stages are described based on activities that trigger the emergence of costs. Based on the data collection, the initial model of the cocoa oil industry production chain on research location is as follows (Figure 3):

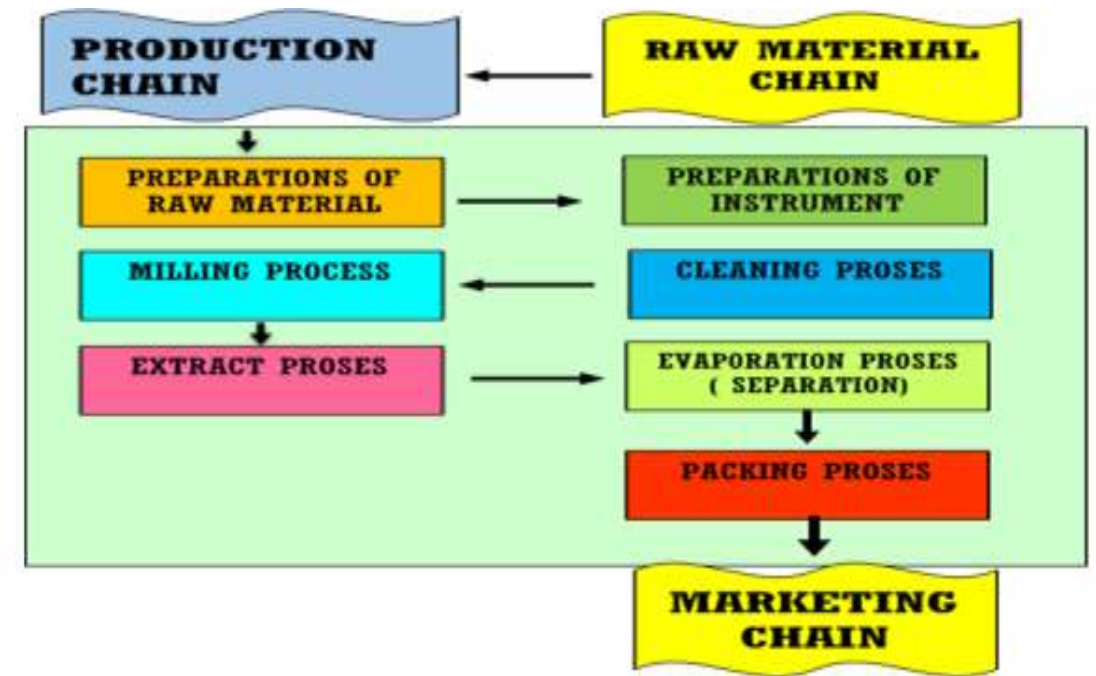

Figure 3 Initial Model of Production Chain of Cocoa Oil Industry 
Based on Figure 3, it can be seen that in general, the process of producing cocoa oil has 7 (seven) stages of production, namely:

- Main Raw Material Preparation Stage: At this stage, the required material is $10 \mathrm{~kg}$ of dry cocoa beans. The cost required for this stage is Rp. 200.000, - i.e. for the purpose of purchasing the main raw material (dried cocoa beans).

- Equipment Setup Stages: at this stage, all equipment needed in the process of producing cocoa oil should be ready for use. The type of equipment needed is among others: (a) grinder; (B) scales; (C) filter paper; (D) extraction / soxhelet; And (e) a vaporizer (vacuum evaporator). At this stage, it is assumed that all required equipment falls into the category of fixed assets, so it is not included in the component to form the production cost, in the sense that at this stage, does not trigger the production cost.

- Cleaning Stage. In this stage, dried cocoa beans are first cleaned from the dirt. In this stage, the cleaning process is done by using a clean cloth or brush. In this stage it also does not raise the cost of production with the assumption that the materials used in this stage are the fixtures that fall into the category of fixed assets.

- Milling Stage (Smoothing). The grinding process aims to smooth the dry cocoa beans to be extracted. The smoothing process is done by using a cocoa bean grinder. In this stage it also does not raise the cost of production with the assumption that the material used in this stage is the milling equipment that fall into the category of fixed assets.

- Extraction Phase. At this stage, the extraction is carried out by the following mechanisms: (a) dry, crushed cocoa beans are fed into a filter paper where the size is adjusted to the size of the extract machine; (B) as a solvent, 96\% ethanol is used in the amount of 10 liters (comparison: $1 \mathrm{~kg}$ dry cocoa beans, using 1 liter of ethanol solvent); (C) furthermore, an extract machine already containing crushed cocoa beans, then boiled for about 120 to 190 minutes; (D) the result of this extraction process is a mixture of cocoa oil with solvent. At this stage, the required cost is Rp. 300.000, - ie for the purchase of 10 liters of ethanol $96 \%$ with the price of Rp. 30.000, - purchased around the business location, and Rp. 20.000, - for the purchase of filter paper.

- Evaporation stage (separation). After the extraction, process is complete, then the evaporation process is done. The evaporation process is a continuation of the extraction process in order to separate the brown oil from the solvent ( $96 \%$ ethanol) to obtain a clear yellow to brown cocoa oil extract. In this evaporation process used equipment namely; Vacuum evaporation. In this stage there is no production cost assuming that the equipment used in this stage is the equipment classified as fixed assets and the cost of fuel as collective cost.

- Packaging Stage. At this stage, cocoa oil products are put into bottled and labeled packaging. The net content of packaged cocoa oil is $100 \mathrm{ml}$. Costs incurred for this stage are the cost of plastic materials and simple packaging labels, which is assumed to be Rp. 20.000, - / bottle.

The costs identified in relation such cocoa oil production activities are not included in the costs incurred for fuel and labor. The imposition of the two cost components is not included in the cost listed in the sequence of the production process with the consideration that the cost component is collective and thus difficult to separate according to the number of units of production. For that reason, both components of the cost will be calculated based on the cost of the two components released as a whole. The amount of both components of the cost is issued for a one-time production process (an average of $10 \mathrm{~kg}$ of dry cocoa beans for one production, in accordance with the capacity of the machine), are;

1) Labor Cost. The labor used for a single cocoa production process is an average of 3 people, with an average salary per person can be calculated as follows: (a) Direct monthly labor cost is Rp. 1.500.000, - / person; (b) in each month, the average amount of production is 10 times, so the salary of labor per once production is Rp. 150.000, - / person; (c) so that the total labor cost for 3 workers is Rp. 150.000 , - x 3 people per one time production (10 kg dry cocoa beans) ie; Rp. 450,000, -

2) Fuel Costs. The process of producing dried cocoa beans into cocoa oil is a production process that is full of extraction loads, requiring adequate fuel and electricity for the process. For the calculation of fuel costs, used benchmark $3 \mathrm{~kg}$ LPG gas fuel tube. One LPG gas tube is usually used for one production process (10 $\mathrm{kg}$ cocoa beans). Based on the data, then assuming LPG gas price of $3 \mathrm{~kg}$ tube is Rp. $22.000,-/$ tube, it can be obtained the amount of fuel cost used for one production of $10 \mathrm{~kg}$ of dry cocoa beans to become cocoa oil products is Rp. 22.000, -.

\section{Initial Model of Cocoa Oil Industry Marketing Chain}

The initial model of the cocoa oil industry marketing chain is a model in which marketing activities are outlined based on activities that trigger costs. The marketing chain is a series of follow-up activities in value 
chain activities directed to the process of attributing finished products to consumers, both individual consumers, and industrial consumers. The initial model of the cocoa oil industry marketing chain is as follows:

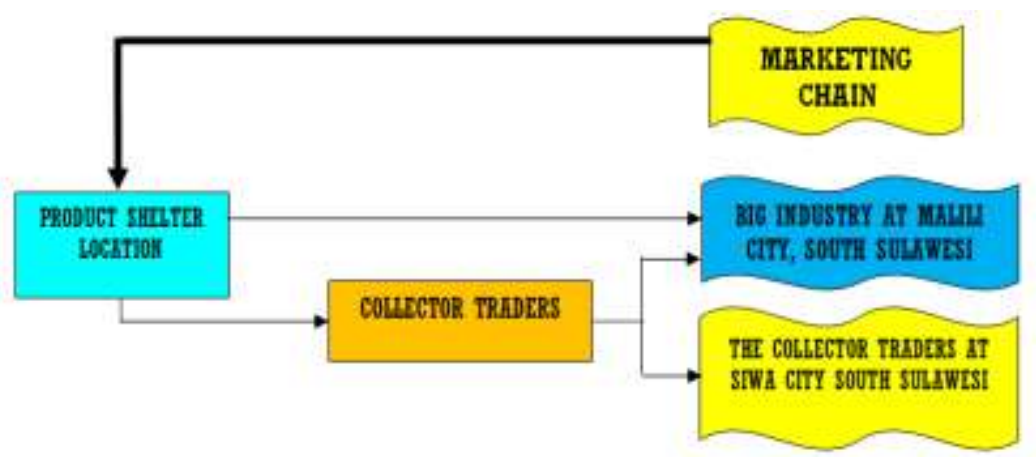

Figure 4. Initial Model of Cocoa Oil Industry Marketing Chain

In the initial model of the cocoa oil industry marketing chain in the Agropolitan Lembah Lanipa area, Pakue Subdistrict, Pakue Tengah Subdistric, Pakue Utara Subdistric, and Batu Putih Subdistrict, it can be seen that after passing through the production process as described in the initial model of the production chain, it is ready to sell cacao products to the location of the finished product shelter in each subdistrict. Based on the results of data collection in the research site, the researcher fpund that all cocoa oil products ready to be sold then dropped to a shelter location, which is more or less an average distance of 1 to $1.5 \mathrm{~km}$ from the production site. The delivery process is done by using motor vehicles with an average wage of Rp. 15,000, - once transport. For a single haul can reach 30 bottles $(1$ bottle $=100 \mathrm{ml})$ of cocoa oil products, so if the transport cost calculated per-unit, then obtained cost of transport at this stage is Rp. 15.000, - / 30 units = Rp. 500, - / unit. The price that applies to every $100 \mathrm{ml}$ of cocoa oil in this location is Rp. $250.000,-$ / bottle $(1$ bottle $=100 \mathrm{ml})$.

After being in the shelter in each subdistrict, then the ready-to-sell cocoa oil products will lead to 2 different marketing locations, namely; (A) Large Company of Cocoa Processing Industry located in Malili City of Luwu Timur Regency of South Sulawesi Province, and (b) collecting merchants. Delivery process from the shelter location to these two locations is fully in the responsibility of the buyer (Big Company of Cocoa Processing Industry and collecting merchant). The purchase price of the Big Company on the ready-to-sell cocoa oil products at the shelter location is Rp. 260.000 , - / $100 \mathrm{ml}$, while the purchase price of the collecting party is approximately Rp. $250.000,-/ 100 \mathrm{ml}$.

Furthermore, for the collecting traders, they sell the cocoa oil products to 2 (two) marketing locations, namely; (A) The Big Traders of Cocoa Processing Industry located in Malili City of Luwu Timur Regency at a price of Rp. 275.000 , - / $100 \mathrm{ml}$. In the case of delivery of products from collecting merchants to large companies in Kota Malili, collecting merchants do not make physical changes or product packaging. The Large Company in Malili City further makes this cocoa oil product as one of the raw materials in the cocoa processing industry; (B) Collector traders in Siwa City of South Sulawesi Province, at a price of Rp. 280.000, - / $100 \mathrm{ml}$. Product delivery system for this marketing channel is by using the Ferry with the route of Port Tobaku of Katoi District, North Kolaka Province to the Port of Siwa, South Sulawesi Province.

Based on the description of the value chain of the cocoa oil industry in this study site, by using the HAYAMI method, it can be calculated the amount of additional value received by the cocoa oil industry community as described in Table 1.

Based on the calculation of value added of initial model of value chain of cocoa oil industry using HAYAMI method in Table 1, it is found that the profit per production (10 kg produce 3 liters of cocoa oil) cocoa processing industry is Rp. 53.000, - with a profit rate of $28.19 \%$. This indicates that the cocoa processing industry in the Agropolitan Lembah Lanipa of Pakue Subdistrict, Pakue Tengah Subdistrict, Pakue Utara Subdistrict, and Batu Putih Subdistrict in North Kolaka Regency has been able to provide positive additional value to business community although the profit level is still small. The underlying factor causing the low level of margin obtained by business community is the high level of intervention from dry cocoa bean collectors which is the main raw material in cocoa oil production process, especially in affecting the price level of dry cocoa beans around the business location.

Based on the calculation of value added of initial model of cocoa oil industry value chain using Hayami method, it can be seen that for the remuneration of factors of production, the highest portion of the remuneration of factors of production is found in other input contribution namely; $65.81 \%$ and workforce of $24.55 \%$. This indicates that from the gained added value composition, $65.81 \%$ of the value added portion is allocated for the 
cost of input contribution (main raw material and auxiliary raw materials), while $24.55 \%$ is allocated for labor service portion, the rest Of $9.64 \%$ is a portion for business profits.

From the calculation of additional value, it can be seen that the high cost incurred to obtain the main raw materials and auxiliary materials as well as the remuneration of labor is the main factor that cause the low of business margin received by cocoa oil business community in this research.

Table1.

Calculations Of Additional Value Of Cakao Oil Industry Initial Models (Standard Calculation Once Produced $=10 \mathrm{Kg}$ of Dry Cocoa Beans)

\begin{tabular}{|c|c|c|}
\hline NO & VARIABLE & VALUE \\
\hline \multicolumn{3}{|c|}{ OUTPUT, INPUT, AND PRICE } \\
\hline 1 & OUTPUT (liter / Production) & 3 liters \\
\hline 2 & RAW MATERIAL (Kg/ Production) & $10 \mathrm{Kg}$ \\
\hline 3 & LABOR (Person / Production)) & 3 persons \\
\hline 4 & CONVERTION FACTORS & 0,3 \\
\hline 5 & LABOR COOPERATION & 0,3 \\
\hline 6 & OUTPUT PRICE & Rp. $2.500 .000,-/ 1$ iter \\
\hline 7 & WAGES AVERAGE TK (Rp/Production) & Rp. $450.000,-$ \\
\hline \multicolumn{3}{|c|}{ REVENUES AND BENEFITS } \\
\hline 8 & RAW MATERIAL PRICE & Rp. 200.000,- \\
\hline 9 & OTHER INPUT PAYMENTS & Rp. 362.000,-- \\
\hline 10 & OUTPUT VALUE & Rp. 750.000,-/prod \\
\hline \multirow[t]{2}{*}{11} & A. ADDED VALUE & Rp. 188.000,-/prod \\
\hline & B. ADDITIONAL RATIO RATING & $25,07 \%$ \\
\hline \multirow[t]{2}{*}{12} & A. EMPLOYMENT BENEFITS & Rp. 135.000,- \\
\hline & B. PART OF WORK & $71,81 \%$ \\
\hline \multirow[t]{2}{*}{13} & A. BENEFITS & Rp. 53.000,- \\
\hline & B. BENEFITS & $28,19 \%$ \\
\hline \multicolumn{3}{|c|}{ REVERSE THE OWNER OF THE OWNER OF THE PRODUCTION FACTOR } \\
\hline \multirow[t]{4}{*}{14} & MARGIN BENEFITS & Rp. 550.000,-/prod \\
\hline & A. ADVANTAGES & $9,64 \%$ \\
\hline & B. LABOR & $24,55 \%$ \\
\hline & C. OTHER INPUT & $65,81 \%$ \\
\hline
\end{tabular}

Source: Calculation Result with HAYAMI Method for Initial Model

\section{Value Chain Development Model of Cocoa Industry}

In the previous section, it has been explained that this research is a multi-year research where the goal in this first year is to construct the formation of cocoa oil industry value chain development model which can give sustainable additional value.

Based on the initial model of the value chain of cocoa oil industry that previously built, then the researcher will construct the development of the model. The process of developing the initial model of the value chain of cocoa oil industry will be done by using activity based costing (ABC) concept.

The ABC (Activity Based Costing) method is another alternative to traditional financing methods over overhead costs. This concept arises because it is considered that the traditional method is not appropriate in allocating overhead costs to production only by relying basis of direct materials, direct wages or production units only. Based on this concept, this kind of imposition is improper and will be able to provide misinformation in providing information about production costs, therefore $\mathrm{ABC}$ offers that the overhead charge is also based on a proportional percentage to other costs or to the product. However, to the activities undertaken to produce the goods, the concern is the element that drives the cost (cost driver) not the product. If this concept is applied then the decision making will be more appropriate and the business will not be lose due to unit cost error.

$\mathrm{ABC}$ (Activity Based Costing) is a system of cost accumulation and charging cost to the product by using various cost driver, done by tracing cost from activity and then tracing cost from activity to product. The benefits of implementing $\mathrm{ABC}$ are:

1) Determining the cost of products more accurately, especially to eliminate cross-subsidy so that there is no loading over of basic price kinds (over costing) and other under-cost product.

2) Improving decision-making. By using $\mathrm{ABC}$ not only provide more accurate information about product cost, but also provide information for business community about the activities that lead to the cost, especially indirect costs, which is important for management in making decisions both on products and in managing the activities -activity so as to improve the efficiency and effectiveness of the business.

3) Enhancing control over overhead. Overhead costs caused by activities that occur in the company. ABC system facilitates business community in controlling the activities that cause the overhead. 
The stages in the application of $\mathrm{ABC}$ are as follows:

A. Identify activities. The identification of activities requires a listing of the types of jobs within the company related to the production process.

B. Charging fees to activities. Each time an activity is set, the cost of implementing the activity is determined.

C. Specifies the activity driver. The next step is to determine the activity driver for each activity, which is the controlling factor of the activities.

D. Determining tariff. In determining this rate, the total cost of each activity is divided by the total activity of the driver used for the activity.

E. Charging the product. The next step is to multiply the rate obtained for each activity with the driver activity consumed by each type of product produced and then divide by the number of units produced for each product.

\section{Model of Raw Material Industry Chain Development}

The cocoa oil industry raw material development model is a model developed based on the initial model of the raw material chain that has been prepared previously. Based on the results of ABC and FGD analysis conducted, the model of cocoa oil industry raw material development in the research location is as follows:

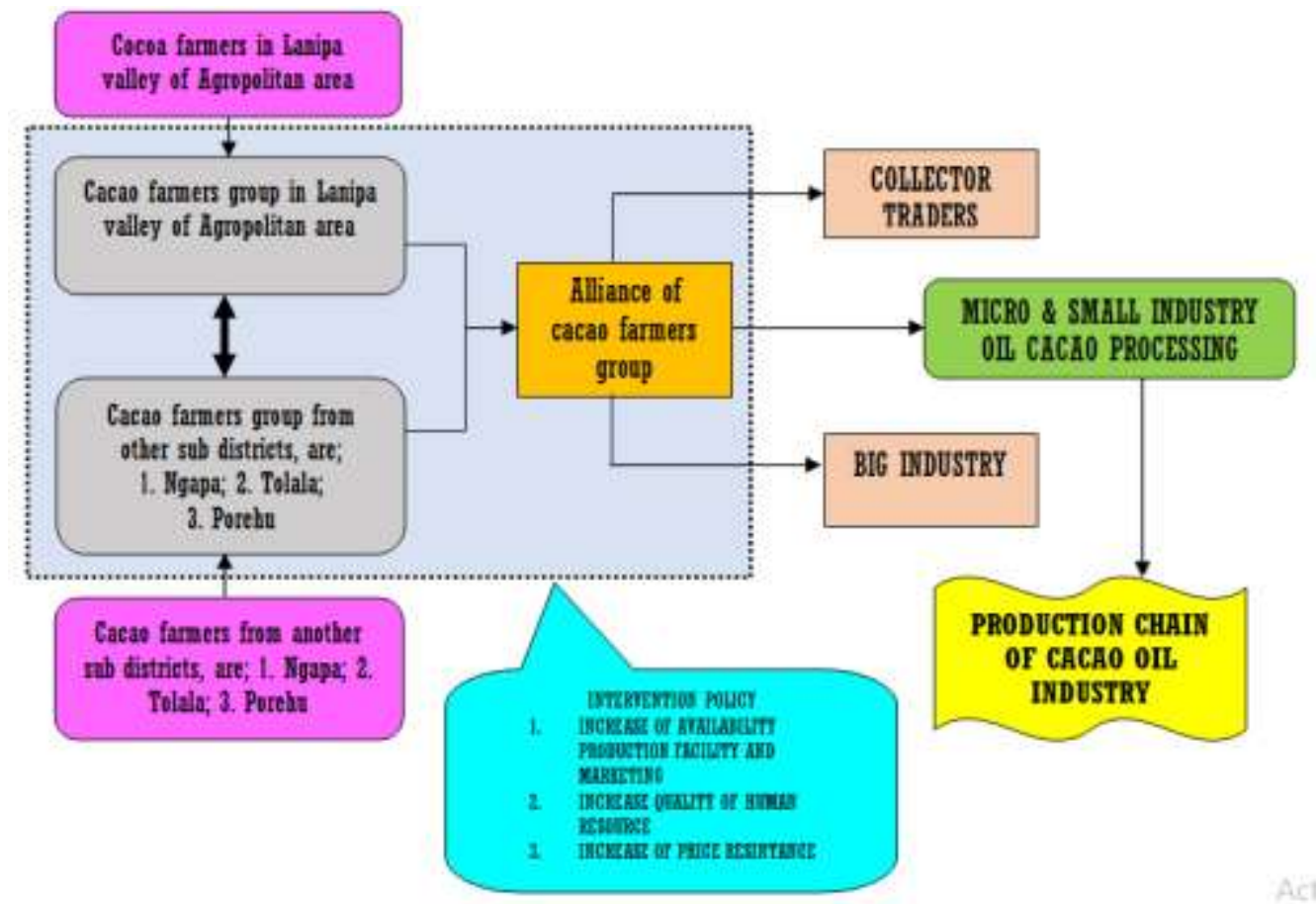

Figure 5. Model of Raw Material Industry Chain Development

Based on the result of activity based costing (ABC) and focus group discussion, the researcher then construct the model of cocoa oil industry raw material development as shown in Figure 5. Several points that become the development initial model of cocoa oil industry raw material are:

1) Supply of raw materials in the initial model is supplied from 2 (two) sources namely; (1) Traders of dry cocoa bean collectors in the Agropolitan Lembah Lanipa area with an average price of Rp. 20,000, - / kg; And (2) Collecting traders of dry cocoa beans from other sub-districts, with an average price of Rp. 20.000, - / kg. Based on the results of ABC and FGD analysis then the researcher obtained results as follow:

a) For the source of raw material, it is expected that the cocoa industry can obtain the raw materials either directly from the cocoa farmers located in the Agropolitan Lembah Lanipa area or from other subdistricts located close to the production pole; (1) Ngapa Subdistrict; (2) Tolala Subdisttric; And (3) Porehu Subdistrict.

b) Each cocoa farmer in the agropolitan Lembah Lanipa and cocoa farmers located in other subdistricts adjacent to the poles of production, is expected to establish Cocoa farmers group (Poktan) for each subdistrict and then to form a Cocoa Farmers Group association (Gapoktan) for the entire farmer groups. This is done with the consideration that farmer groups and farmer group associations can be become institutions that are able to stabilize prices in accordance with prevailing market prices.

c) The selling price of dried cocoa beans at the farmer group level or the combination of farmer groups is predicted to be in the range of $\mathrm{Rp} .18,500,-/ \mathrm{kg}$ with the consideration that the current price at the farmer 
level is currently Rp. 17.000, - / kg and at the collecting merchant level is Rp. 20.000 , - / kg, therefore if this can be implemented it will have a positive impact in the form of increase in selling prices at the farmers level, and decrease in the purchase price of raw materials at the level of cocoa oil business community.

2) Regional Regulation Factor. The government should establish an intervention policy at the farmer group level, whether located in the research location or in the region adjacent to the production poles, the price of the dry cocoa beans applicable to the cocoa industry is set at, Rp. 18,500, - / $\mathrm{kg}$. This is based on the consideration that if the cocoa oil industry in this region is increased, the positive impacts that can be gained by the region is the increased economic added value, the absorptive capacity of the workforce and can the reduction of poverty rate. In addition, the form of intervention policies that can be granted in the framework of developing the cocoa oil industry is; improving the quality of human resources, and increasing the availability of production facilities and infrastructure.

3) There is a need for a partnership with cocoa farmers in other adjacent areas, such as; Ngapa Subdistrict, Tolala Subdistrict, and Porehu Subdistrict, so the cocoa industry community do not experience the scarcity of main raw materials. However, this can only be done if there is support from the local government in the improvement of supporting facilities and infrastructures, such as; Means of transportation to facilitate the flow of raw material mobility from the poles of raw materials to the poles of production.

The Model of Production Chain Development of Cocoa Oil Industry.

The cocoa oil industry's production chain development model is a model developed based on the initial production chain model. The development of this production chain model is constructed by using activity based costing (ABC) and focus group discussion (FGD). Based on the results of the analysis, the Model of Production Chain Development of Cocoa Oil Industry in Pakue, Pakue Tengah, Pakue Utara, and Batu Putih Subdistricts can be explained in Figure 6.

Based on the results of $\mathrm{ABC}$ analysis and the information obtained from the FGD results showed that the production stages contained in the initial model of the production chain (Figure 6) are standardized stages, therefore, that the initial model development process is only focused on the raw materials and equipment preparation. The current packaging process in the initial model is the packaging in the form of a bottle which is then given a label of simple paper that inscribed the name of the product, price and production address.

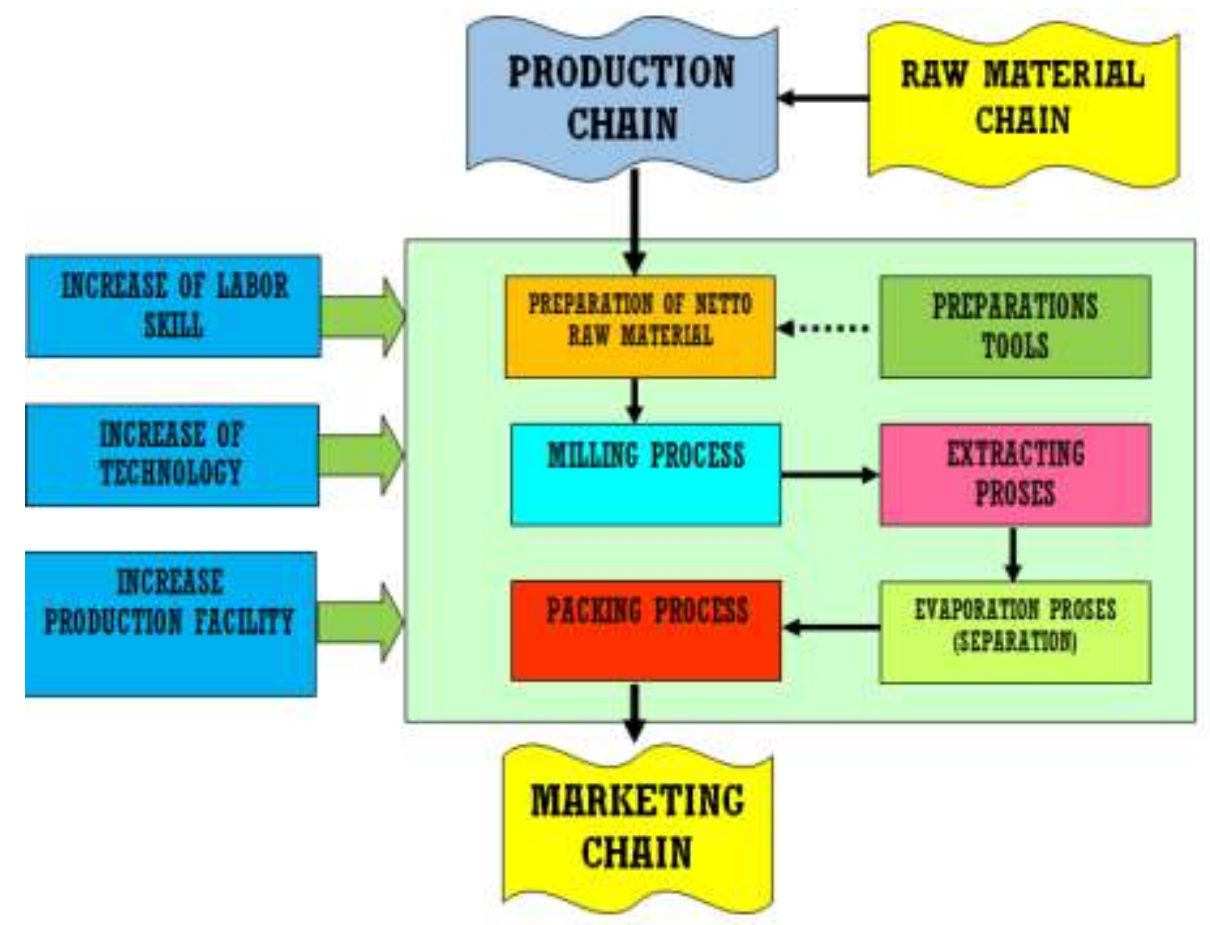

Figure 6 Model of Production Chain Development of Cocoa Oil Industry

The results of $\mathrm{ABC}$ analysis and FGD implementation result indicate that some of the things that become the development of the early model of cocoa oil industry production chain are;

1) Preparation and cleaning activities of raw materials are in one stage activity, so that both of these activities decided to be done through a series of activities namely; clean of material preparation activities. Merging these two activities can shorten the cycle of production activity. While for equipment preparation activity, it 
is not included in the production chain activity cycle but is considered as an activity supporting the production cycle.

2) Modification of Extraction Activity. In the initial model of the production chain, the extraction was carried out using a solvent (96\% ethanol) with a total of 10 liters at a cost of Rp. 300.000, - i.e. for the purchase of 10 liters of solvent with a price of $\mathrm{Rp} .30 .000$, -. The price is the prevailing price around the business location. Based on the FGD results, researcher found that the price of solvents per liter in the area of South Sulawesi Province is Rp. 26.000, - / liter, so with reference to the information, it is deemed necessary to form a joint business cooperative that serves as a solvent distributor from the South Sulawesi Province to the cocoa oil industry community in the research location. Estimated pricing if this is implemented is Rp. 28,500, - / liter, with details as follows: (a) Rp. 26,000, - is the purchase price in South Sulawesi Province; (B) Rp. 2.000, - represents the transportation cost / liter, and Rp. 500, - represents the margin received by the joint venture cooperative.

3) Based on FGD results, it is found that there are some obstacles that are often faced by cocoa oil industry business community, they are; (A) inadequate labor skills; (B) lack of use of production technology that can improve production quality; And (c) lack of availability of production facilities and infrastructure. Based on this information, it is necessary to run a strategic procedures that can overcome these problems such as Increasing training intensity for industry players, increasing availability of production facilities and infrastructure, and improving the production technology through research in cooperation with related parties such as; Government, universities, non-government organizations, and other relevant parties.

\section{The Development Model of Cacao Oil Marketing Industry Chain}

The cocoa oil industry's marketing development model is a model developed based on the preliminary model of the marketing chain. The development of this chain of marketing model is constructed by using Activity Based Costing (ABC) and Focus Group Discussion (FGD). Based on the results of the analysis, the Model of Marketing Chain of Cocoa Industry in Pakue, Pakue Tengah, Pakue Utara, and Batu Putih Subdistrict (Figure 7) was obtained.

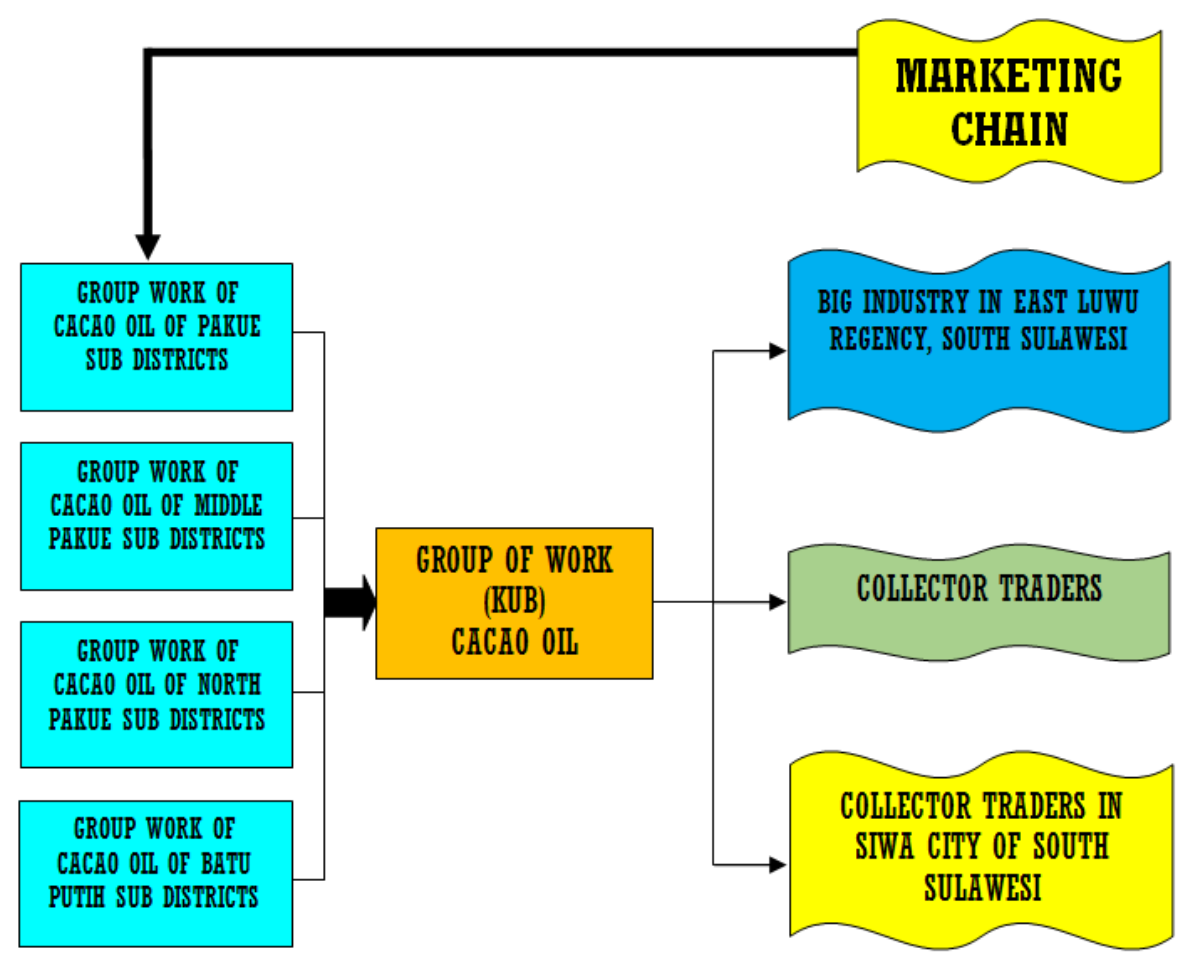

Figure 7 The development model of marketing cacao oil industry

Based on ABC analysis and FGD implementation it is deemed necessary to establish cocoa oil industry groups in the research location. This is done to replace the role of shelter location that is economically not provide added value for cocoa oil industry community. In addition, the existence of shelter location does not create added value and only become the cost driver for the business. Therefore, in the simulation of this chain of marketing development model, the existence of the shelter location is omitted and replaced with the group works. The collector trader in this research is expected to come directly to the cocoa oil industry group work to make purchases of ready-to-sell products. Estimated selling price at the business group level in each sub-district, 
as well as at the level of joint business group is Rp. 26.000 , - / $100 \mathrm{ml}$. If this is implemented then it is projected that the potential increase in cocoa product selling price is Rp. 1,000, - / $100 \mathrm{ml}$.

Figure 2.

Calculations Of Additional Value Projection Model Of Cakao Oil Industry Development (Standard Calculation Once Produced $=10 \mathrm{Kg}$ of Dry Cocoa Beans)

\begin{tabular}{|l|l|l|}
\hline NO & VARIABLE & VALUE \\
\hline OUTPUT, INPUT, AND PRICE & 3 liters \\
\hline 1 & OUTPUT (liter / Production) & $10 \mathrm{Kg}$ \\
\hline 2 & RAW MATERIAL (Kg/Production) & 3 persons \\
\hline 3 & LABOR (Person / Production) & 0,3 \\
\hline 4 & CONVERTION FACTORS & 0,3 \\
\hline 5 & LABOR COOPERATION & Rp. $2.600 .000,-/ 1$ iter \\
\hline 6 & OUTPUT PRICE & Rp. $450.000,-$ \\
\hline 7 & WAGES AVERAGE TK (Rp/Production) & \\
\hline \multicolumn{2}{|l|}{ REVENUES AND BENEFITS } & Rp. $185.000,-$ \\
\hline 8 & RAW MATERIAL PRICE & Rp. $347.000,-$ \\
\hline 9 & OTHER INPUT PAYMENTS & Rp. $780.000,-/$ prod \\
\hline 10 & OUTPUT VALUE & Rp. $248.000,-/$ prod \\
\hline 11 & A. ADDED VALUE & $31,80 \%$ \\
\hline \multicolumn{2}{|l|}{ B. ADDITIONAL VALUE RATE } & Rp. $135.000,-$ \\
\hline 12 & A. EMPLOYMENT BENEFITS & $54,44 \%$ \\
\hline \multicolumn{2}{|l}{ B. PART OF WORK } & Rp. $113.000,-$ \\
\hline 13 & A. BENEFITS & $45,56 \%$ \\
\hline \multicolumn{2}{|l|}{ B. BENEFITS OF ADVANTAGE } & \\
\hline REVERSE THE OWNER OF THE OWNER OF THE PRODUCTION FACTOR & \\
\hline 14 & MARGIN BENEFITS & Rp. $595.000,-/$ prod \\
\hline & A. ADVANTAGES & $18,99 \%$ \\
\hline & B. LABOR & $22,69 \%$ \\
\hline & C. OTHER INPUT & $58,32 \%$ \\
\hline
\end{tabular}

Source: Calculation Result With HAYAMI Method for Initial Model

Furthermore, in order to provide a clear description of the additional value change of the initial model of the cocoa oil industry value chain compare to the development model that has been formed, the researcher made a comparison of value added projection as follows:

Figure 3.

Projections Comparison Of Value-Added Increasing Between Early Models And Development Models Of Cocoa Oil Industry Value Chain (one production activity standard Calculation $=10 \mathrm{Kg}$ )

\begin{tabular}{|c|c|c|c|}
\hline \multirow[t]{2}{*}{ NO } & \multirow[t]{2}{*}{ VARABLE } & \multicolumn{2}{|l|}{ VALUE } \\
\hline & & Model Ear & Model Development \\
\hline \multicolumn{4}{|c|}{ OUTPUT, INPUT, AND PRICE } \\
\hline 1 & OUTPUT (Kg/Production) & 3 liter & 3 liter \\
\hline 2 & RAW MATERIAL (Kg/ Production) & $10 \mathrm{Kg}$ & $10 \mathrm{Kg}$ \\
\hline 3 & LABOR PEOPLE (Person/ Production) & 3 person & 3 person \\
\hline 4 & CONVERTION FACTORS & 0,3 & 0,3 \\
\hline 5 & LABOR COEFFICIENT & 0,3 & 0,3 \\
\hline 6 & OUTPUT PRICE & Rp. 2.500.000,-/1iter & Rp. 2.600.000,-/1iter \\
\hline 7 & WAGES AVERAGE TK (Rp/ Production) & Rp. 450.000,- & Rp. 450.000,- \\
\hline \multicolumn{4}{|c|}{ REVENUES AND BENEFITS } \\
\hline 8 & RAW MATERIAL PRICE & Rp. 200.000,- & Rp. 185.000,- \\
\hline 9 & OTHER INPUT PAYMENTS & Rp. 362.000,- & Rp. 347.000,- \\
\hline 10 & OUTPUT VALUE & Rp. 750.000,-/prod & Rp. $780.000,-/$ prod \\
\hline \multirow[t]{2}{*}{11} & A. ADDED VALUE & Rp. 188.000,-/prod & Rp. 248.000,-/prod \\
\hline & B. ADDITIONAL RATIO RATING & $25,07 \%$ & $31,80 \%$ \\
\hline \multirow[t]{2}{*}{12} & A. EMPLOYMENT BENEFITS & Rp. 135.000,- & Rp. 135.000,- \\
\hline & B. PART OF WORK & $71,81 \%$ & $54,44 \%$ \\
\hline \multirow[t]{2}{*}{13} & A. BENEFITS & Rp. 53.000,- & Rp. 113.000,- \\
\hline & B. LEVEL OF ADVANTAGES & $28,19 \%$ & $45,56 \%$ \\
\hline \multicolumn{4}{|c|}{ REFERSE THE OWNER OF THE PRODUCTION FACTORS } \\
\hline \multirow[t]{4}{*}{14} & MARGIN BENEFITS & Rp. 550.000,-/prod & Rp. 595.000,-/prod \\
\hline & A. ADVANTAGES & $9,64 \%$ & $18,99 \%$ \\
\hline & B. LABOR & $24,55 \%$ & $22,69 \%$ \\
\hline & C. OTHER INPUT & $65,81 \%$ & $58,32 \%$ \\
\hline
\end{tabular}

Source: HAYAMI Calculation Results for Early Model and Development Model 
Based on the result of comparison of added value between initial model and cocoa oil industry value chain development model, it can be seen that:

1) The results of development model of value chain of cocoa oil industry resulted in the increase of product selling price from Rp. 2.500.000, - / liter in the initial model to Rp. 2.600.000, - / liter on the development model.

2) The price of the main raw material (dried cocoa beans) in the initial model is Rp. 200.000 , - / production decreased to Rp. 185.000, - / production on the development model.

3) Fees for other input contributions from Rp. 362.000 , - / production on the initial model, dropped to Rp. $347.000,-$ / production on the development model.

4) An increase in the output value of the initial model is Rp. 750.000, - / production to Rp. 780.000, - / production on cocoa oil industry value chain development model.

5) There is an increase of product added value from Rp. 188.000, -, - / production on the initial model, to Rp. $248.000,-/$ production on the development model resulting in an increase of profit from Rp. 53.000, - / production on the initial model to Rp. 113.000, - / production on the development model.

6) Increased profit margin from Rp. $550.000,-/ \mathrm{kg}$ on the initial model to Rp. $595.000,-/ \mathrm{kg}$ on the development model.

7) There was a decrease in the margin portion of the labor cost factor of $24.55 \%$ in the initial model, to $22.69 \%$ in the development model.

\section{Managerial Implications}

The implementation of the cocoa oil industry value chain development model that is generated in this research are focused on the development of raw material chain and production chain. Increasing value added on this development model can be achieved if supported by several things, namely; (1) it is necessary to have an intervention policy from the local government, especially in terms of institutions and partnerships; (2) it is necessary to increase the availability of supporting facilities; (3) improving the quality of human resources; and (4) improvement of production technology.

\section{Conclusion}

\section{Conclusions And Recommendations}

The cocoa oil industry value chain development model is projected to be; (1) increase the selling price of the product; (2) reduce the purchase price of the main raw materials (dry cocoa beans); (3) lower costs for other input contributions; (4) increase output value; (5) increase product added value; (6) increase profits; (7) increase profit margins; and (8) decrease the portion of margin on the compensation of labor factors of production.

\section{Suggestion}

Based on the results of this first year research, the researcher mention some suggestion as follows:

1) There is a need for special attention from the Government in determining the regulation in terms of intervention policies for raw material supply and improvement of facilities and supporting infrastructure of the cocoa oil industry in North Kolaka Province.

2) Some trainings for cocoa oil industry business community are required, especially in terms of production technology.

3) There is a need for partner institutions for cocoa oil industry business community, especially partners related to capital and production techniques.

4) There is a need for improvement of supporting facilities and infrastructure to support the development of the cocoa oil industry in North Kolaka, especially in Pakue, Pakue Tengah, Pakue Utara, and Batu Putih subdsitrict.

\section{References}

[1] Akyol DE, Tuncel G, dan Bayhan GM. 2005. A Comparative Analisys of Activity Based Costing and Traditional Costing. Izmir; World Academy of Science, Engineering, and Technology.

[2] Faisal W. I. 2010. Sustainable Palm Oil Value Chain Analysis. Thesis. Master in Business. Graduate Institute of Bogor Agriculture. Bogor.

[3] Hansen, and Mowen. 2000: Cost Management; Accounting and Control. Salemba Empat. Jakarta.

[4] Jantje G. K, and Bachtiar. (2010). Implementation of Value Chain Analysis in the Framework of Acceleration of Agricultural Sector Development in North Sulawesi. Regional Seminar on Innovation of Agricultural Technology of North Sulawesi Province. Manado.

[5] Porter, M. E. (1985). Competitive Advantage: Creating and Sustaining Superior. New York: The Free Press.

[6] Prockel PV, Gray A, Bochlje M, Kim S. 2004. Risk and Value Chains; Participant Sharing of Risk and Rewards. J Chain and Network Services. Vol. 4 (1). pp 25-32.

[7] Romney, Marshall, et al. 2000. Accounting Information Systems. Eights Edition. New Jersey. Prentice Hall.

[8] Shank, J.K., and Govindarajan, V. 1992. Strategic Cost Management and the Value Chain, Thomson Learning. USA. 
[9] Syarif H., Marimin., Suryani A., Yani M. 2012. Modification of Hayami Method for Calculation of Added Value on Supply Chain of Palm Oil Agroindustry. Journal of Agricultural Industrial Technology. Vol. 22. No. 1; P. 22-31.

[10] Wisdaningrum, O. 2013. Value Chain Analysis in the Company's Internal Environment. ANALYSIS. Vol.1. Number 1. April 2013.

[11] Worthington AC dan Tracey W. 2001. Economic Value-Added: A Review of the Theoritical and Empirical Literature. Asian Rev Accounting. Vol. 9. No. 1. pp. 67-86

[12] Yuliana, Yenti. O. 2001. REA Model Approach in Database Design of Revenue Accounting Information System Cycle. Journal of Accounting and Finance. Vol. 3. No. 1. May 2001. 67-88.

[13] Yuwono D.M, Muryanto and Sherly S. P. 2012. Value Chain Analisys (VCA) of Local Chicken Agribusiness in Desa Wonosari, Bawang Sub-District, Batang Regency. Paper. National Seminar on Food Sovereignty and Energy. Faperta Trunujoyo University . Madura.

[14] Zaid, Sudirman. (2016). Study on Increasing local Competitiveness of Superior-based Commodity in Southeast Sulawesi. JAM Bisnis MM UHO. Vol. 6. No. 1. Pg. 77-85. 